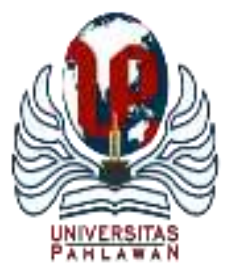

Edukatif : Jurnal Ilmu Pendidikan Volume 4 Nomor 1 Tahun 2022 Halm 1341 - 1348

EDUKATIF: JURNAL ILMU PENDIDIKAN

Research \& Learning in Education

https://edukatif.org/index.php/edukatif/index

\title{
Implementasi Kebijakan Merdeka Belajar Kampus Merdeka di Universitas Abdurrab pada Program Magang Mahasiswa
}

\author{
Amir Syamsuadi $^{1 凶}$, Harni Sepriyani $^{2}$, Susi Endrini $^{3}$, Ade Febriani $^{4}$ \\ Universitas Abdurrab, Indonesia ${ }^{1,2,3,4}$ \\ E-mail : amir.syamsuadi@ univrab.ac.id ${ }^{1}$, harni.sepriyani@univrab.ac.id ${ }^{2},{\underline{\text { sendrini } @ u_{\text {univrab.ac.id }}}}^{3}$, \\ ade.febriani@univrab.ac.id ${ }^{4}$
}

\begin{abstract}
Abstrak
Tujuan dari penelitian ini adalah untuk mengukur dan menggambarkan analisis implementasi kebijakan MBKM Universitas Abdurrab dalam program magang mahasiswa. Metode penelitian ini adalah metode campuran atau Mixed Method Research (MMR) dengan pendekatan kuantitatif menggunakan metode survei dan pendekatan kualitatif menggunakan metode wawancara. Hasil penelitian menunjukkan bahwa mayoritas responden (>80\%) menyatakan sangat dan setuju terhadap implementasi kebijakan MBKM Universitas Abdurrab terkait program magang mahasiswa, cukup setuju (>10\%) dan kurang setuju dan tidak setuju hanya $<1 \%$. Kesimpulan yang diperoleh yaitu Universitas Abdurrab telah mengimplemetasikan kebijakan MBKM terutama dalam program magang mahasiswa yakni dengan menempatkan mahasiswa Universitas Abdurrab untuk program magang di beberapa instansi terkait seperti rumah sakit, puskesmas dan perusahaan. Universitas Abdurrab juga telah mengimplementasikan kebijakan MBKM untuk program magang mahasiswa di prodi-prodi yang dijadikan percontohan pelaksanaan program magang di Universitas Abdurrab.
\end{abstract}

Kata Kunci: Kebijakan, Magang, Kampus

\section{Abstract}

The purpose of this study is to measure and describe the analysis of the implementation of the MBKM policy at Universitas Abdurrab in the student internship program. This research method is a mixed research method with a quantitative approach using a survey method and a qualitative approach using an interview method. The results showed that the majority of respondents (>80\%) stated strongly and agreed with the implementation of the MBKM policy of Universitas Abdurrab related to the student internship program, quite agreed (>10\%) and disagreed and disagreed only $<1 \%$. The conclusion obtained is that Universitas Abdurrab has implemented the MBKM policy, especially in the student internship program, namely by placing Universitas Abdurrab students for internship programs in several related institutions such as hospitals, health centers, and companies. Universitas Abdurrab has also implemented the MBKM policy for student internship programs in study programs that serve as pilots for the implementation of the internship program at Universitas Abdurrab.

Keywords: policy, internship, campus

Copyright (c) 2022 Amir Syamsuadi, Harni Sepriyani, Susi Endrini, Ade Febriani

$\triangle$ Corresponding author:

Email : amir.syamsuadi@univrab.ac.id

DOI : https://doi.org/10.31004/edukatif.v4i1.2203

ISSN 2656-8063 (Media Cetak)

ISSN 2656-8071 (Media Online)

Edukatif : Jurnal Ilmu Pendidikan Vol 4 No 1 Tahun 2022 p-ISSN 2656-8063 e-ISSN 2656-8071 
1342 Implementasi Kebijakan Merdeka Belajar Kampus Merdeka di Universitas Abdurrab pada Program Magang Mahasiswa - Amir Syamsuadi, Harni Sepriyani, Susi Endrini, Ade Febriani

DOI: https://doi.org/10.31004/edukatif.v4i1.2203

\section{PENDAHULUAN}

Tren globalisasi dan perkembangan teknologi informasi saat ini telah mendorong kurikulum baru merdeka belajar (Rohiyatussakinah, 2021). Merdeka Belajar Kampus Merdeka (MBKM) merupakan salah satu program unggulan Kementerian Pendidikan dan Kebudayaan (Kodrat, 2021). Merdeka Belajar Kampus Merdeka (MBKM) merupakan kebijakan yang memberikan hak belajar tiga semester di luar program studi bagi mahasiswa (Sulistiyani et al., 2022). Kegiatan MBKM sangat diperlukan guna menghasilkan output yang sesuai kebutuhan masyarakat dan dunia usaha (Nona et al., 2022). Dalam program ini diharapkan mahasiswa dapat meningkatkan kemampuan softskills dan hardskill dengan cara mengikuti salah satu dari delapan program yang ditawarkan. Dengan Program MBKM Program studi yang unggul mampu menciptakan dan mengembangkan kecerdasan intelektual, akhlak mulia, dan keterampilan bagi mahasiswa lulusannya agar dapat bersaing dalam dunia industri (dudi) dan dunia kerja (Krisnanik, Saphira, \& Indriana, 2021). Untuk menjawab perubahan zaman yang dinamis bukanlah persaingan melainkan kerjasama banyak pihak (Kamalia \& Andriansyah, 2021). Kerumitan dan keguncangan pendidikan tidak lagi dianggap sebagai tantangan maupun ancaman, akan tetapi sebagai momentum transformasi dan adaptasi pendidikan digital. Oleh karena itu lembaga pendidikan dituntut untuk dapat merancang kurikulum sekaligus menyiapkan sarana pendukung dan pengembangan yang adaptif (Nasik, 2020). Tidak hanya itu institusi pendidikan tinggi juga perlu mengembangkan metode pembelajaran berbasiskan Merdeka Belajar Kampus Merdeka (Dzikria \& Narulita, 2021).

Berdasarkan kebijakan Peraturan Menteri Nomor. 03 Tahun 2020 yaitu memberikan hak kepada mahasiswa untuk 2 semester belajar di luar program studinya. Magang sendiri merupakan salah satu dari delapan bentuk pembelajaran, yaitu pertukaran belajar, magang/praktik kerja, asistensi mengajar di satuan pendidikan, penelitian/riset, proyek kemanusiaan, kegiatan wirausaha, studi proyek independent, membangun desa (kuliah kerja nyata tematik). Program ini membuka kesempatan bagi mahasiswa untuk memperkaya dan meningkatkan wawasan serta kompetensinya di dunia nyata sesuai minat dan cita-citanya. Pada kebijakan MBKM bagi pengelola PT, wajib memfasilitasi hak bagi mahasiswa untuk dapat mengambil SKS di luar perguruan tinggi paling lama 2 semester atau setara dengan 40 SKS dan dapat mengambil SKS di program studi yang berbeda di perguruan tinggi yang sama sebanyak 1 semester atau setara dengan 20 SKS. Pada tingkat fakultas, harus menyiapkan fasilitasi daftar mata kuliah tingkat fakultas yang bisa diambil mahasiswa lintas prodi dan menyiapkan dokumen kerja sama dengan mitra yang relevan (Sudaryanto, Widayati, \& Amalia, 2020).

Carl J Federick mendefinisikan kebijakan sebagai serangkaian tindakan/kegiatan yang diusulkan seseorang, kelompok atau pemerintah dalam suatu lingkungan tertentu dimana terdapat hambatan-hambatan (kesulitan-kesulitan) dan kesempatan-kesempatan terhadap pelaksanaan usulan kebijaksanaan tersebut dalam rangka mencapai tujuan tertentu (Agustino, 2008). Pendapat ini juga menunjukan bahwa ide kebijakan melibatkan perilaku yang memiliki maksud dan tujuan merupakan bagian yang penting dari definisi kebijakan, karena bagaimanapun kebijakan harus menunjukan apa yang sesungguhnya dikerjakan daripada apa yang diusulkan dalam beberapa kegiatan pada suatu masalah (Syamsuadi, Hartati, Trisnawati, \& Arisandi, 2020).

Di Indonesia, pemagangan salah satunya diatur dalam Permenaker No. 06 Tahun 2020 pasal 1, pemagangan adalah bagian dari sistem pelatihan kerja di Instansi pelatihan dengan bekerja secara langsung di bawah bimbingan dan pengawasan instruktur atau pekerja berkompetensi dalam proses produksi barang dan/atau jasa di perusahaan dalam rangka menguasai keterampilan atau keahlian tertentu (Permenaker No. 06 Tahun 2020 tentang Penyelenggaraan Pemagangan di Dalam Negeri RI) Pemagangan bisa dilakukan karena keinginan pribadi dari mahasiswa atau sebagai bagian dari persyaratan wajib yang harus ditempuh mahasiswa dan dihitung penilaiannya (Hayati, 2021). 
Universitas Abdurrab merupakan salah satu perguruan tinggi yang ada di Provinsi Riau (Yetnimar, Nurjannah, \& Rasyid, 2020). Universitas Abdurrab memiliki 4 fakultas yaitu Fakultas Kedokteran dengan 2 program studi, Fakultas Farmasi dan Ilmu Kesehatan dengan 7 program studi, Fakultas Teknik dengan 3 program studi, serta Fakultas Psikologi dan Ilmu Sosial Politik dengan 3 program studi (Afitri, 2020). Sebagai salah satu perguruan tinggi swasta (PTS) Universitas Abdurrab sudah semestinya mengambil peran dalam pelaksanaan kebijakan MBKM. Pelaksanaan program magang di Universitas Abdurrab dilakukan secara langsung ke instansi yang dianggap sesuai dengan program studi misalnya untuk mahasiswa Analis Kesehatan mahasiswa dan Program Studi S1 Kedokteran ditempatkan di Rumah Sakit milik pemerintah dan swasta di Riau, Mahasiswa Prodi D3 Keperawatan ditempatkan di Puskesmas milik pemerintah kecamatan di Riau, Mahasiswa program studi S1 Teknik Sipil ditempatkan pada pembangunan proyek Pemerintah dan swasta di Riau dan mahasiswa teknik informatika ditempatkan magang ke kantor layanan telekomunikasi milik pemerintah maupun swasta di Riau namun untuk kesesuaian format magang di Universitas Abdurrab dengan ketentuan MBKM dalam Permendikbud SN DIKTI No.03 Tahun 2020 menjadi fokus dan lokus dari kajian penelitian ini.

Penelitian sejenis yang memiliki relevansi diantaranya adalah penelitian Zainil Ghulam tahun 2020 dengan topik kajian Implementasi Kebijakan Magang Dan Konseling Warga Berkebutuhan Khusus Di Surabaya. Teori yang digunakan dalam penelitian adalah konseling dan kebijakan publik. Sedangkan metode yang digunakan adalah kualitatif, dengan pendekatan literature review. Alhasil, apa yang dilakukan Pemkot Surabaya justru memperkuat aspek psikologis lulusan sekolah berkebutuhan khusus. Selama magang, mereka mendapatkan pengalaman berharga dan meningkatkan kepercayaan diri setiap peserta. Meski tidak langsung direkrut untuk bekerja di tempat tersebut, sertifikat pasca magang yang mereka miliki, bisa menjadi penguat mereka saat ingin melamar ke perusahaan lain. Jadi, manfaat dari program ini adalah dari segi pelatihan bagi mereka, dan peningkatan kinerja mereka yang tidak kalah dengan mereka yang tidak berkebutuhan khusus (Ghulam, 2020).

Selanjutnya Penelitian Yulius Laga dkk. Tahun 2022 dengan topik Persepsi Mahasiswa Terhadap Kebijakan Merdeka Belajar Kampus Merdeka (MBKM). Hasil survey juga menunjukan mahasiswa merasa kegiatan MBKM dalam pengembangan kompentensi/keterampilan sebagai bekal bekerja setelah lulus 69 persen. Mahasiswa juga merasa tertarik program MBKM yang diadakan oleh Direktorat Jenderal Pendidikan Tinggi, Riset, dan Teknologi 67,54 persen dan merekomendasikan program sebesar 65,57 persen. Dampak Peneltian ini menunjukan bahwa mahasiswa menjadi lebih fleksibel tehadap proses perkuliahan, pengalaman bersama masyarakat dan bekal untuk pekerjaan setelah lulus kuliah (Laga, Nona, Langga, \& Jamu, 2022).

Urgensi dari penelitian ini diantaranya dapat memberikan kontribusi ilmiah terhadap ilmu pengetahuan khususnya pada bidang administrasi dan manajemen kebijakan pendidikan. Kemudian dikontribusikan sebagai sumbangsih dan rekomendasi serta role model pelaksanaan kebijakan MBKM di Universitas Abdurrab terkait program magang dan juga sebagai referensi bagi pihak terkait yang akan melakukan penelitian lanjutan dengan topik mengenai Kebijakan MBKM.

\section{METODE PENELITIAN}

Adapun strategi pelaksanaan dari penelitian ini merupakan dampak dari pelaksanaan program Merdeka Belajar Kampus Merdeka (MBKM) yang dilaksanakan di tingkat Prodi, fakultas, dan Universitas yang juga melibatkan sivitas akademik Universitas Abdurrab. Adapun esensi dari implementasi kebijakan MBKM di Universitas Abdurrab maka fokus penelitian ini adalah Analisis Implementasi Kebijakan MBKM Universitas Abdurrab dalam program magang mahasiswa dengan pendekatan campuran yakni mengelaborasi fenomena dengan menggambarkan Analisis Implementasi Kebijakan MBKM Universitas Abdurrab dalam program magang mahasiswa. Lokasi penelitian di Kampus Universitas Abdurrab dan tempat magang mahasiswa (mitra). Metode yang digunakan dalam penelitian ini adalah metode campuran atau Mixed Method Research 
1344 Implementasi Kebijakan Merdeka Belajar Kampus Merdeka di Universitas Abdurrab pada Program Magang Mahasiswa - Amir Syamsuadi, Harni Sepriyani, Susi Endrini, Ade Febriani

DOI: https://doi.org/10.31004/edukatif.v4i1.2203

(MMR) yaitu metode penelitian yang diaplikasikan bila peneliti memiliki pertanyaan yang perlu diuji dari segi outcomes dan prosesnya, serta menyangkut kombinasi antara metode kuantitatif dan kualitatif dalam suatu penelitian (Masrizal, 2012). Pendekatan kuantitatif digunakan melalui penelitian deskriptif dengan metode survei (Anggito \& Setiawan, 2018), yaitu dengan memberikan kuesioner terhadap mahasiswa aktif Universitas Abdurrab angkatan 2015-2021. Responden dipilih secara acak dan proporsional (proportionate stratified random sampling) dari jumlah mahasiswa secara keseluruhan sebanyak 3295 orang yang peneliti peroleh dari data Sistem Akademik (SIAKAD) Universitas Abdurrab. Penentuan besarnya sampel dari populasi yang diambil peneliti dengan menggunakan rumus Slovin (Rosmiati, Putra, \& Nasori, 2021), sampel penelitan ini berjumlah 356,69 dibulatkan menjadi 357 mahasiswa. Data kualitatif diperoleh melalui wawancara yang dilakukan kepada beberapa orang informan (Sugiyono, 2008). Informan penelitian merupakan pimpinan perguruan tinggi pengambil kebijakan tingkat Universitas yakni Rektor, Wakil Rektor (WR) I bidang akademik, Wakil Rektor (WR) II bidang administrasi keuangan, Wakil Rektor (WR) III bidang penelitian dan pengabdian masyarakat, Direktur Hubungan Masyarakat dan Kerjasama Universitas Abdurrab selaku implementator sekaligus regulator kebijakan MBKM di Universitas Abdurrab, serta perwakilan mitra. Hasil dari analisa data kualitatif digunakan untuk membantu menetukan fokus dan tipe pengumpulan data kuantitatif. Peneliti mengimplementasikan metode kualitatif dan kuantitatif secara bersamaan/simultan.

\section{HASIL DAN PEMBAHASAN PENELITIAN}

Magang menjadi kegiatan yang menarik dalam kebijakan MBKM. Magang memberikan pengalaman kerja profesional kepada mahasiswa secara terstruktur dengan bantuan para ahli di bidangnya (Fatah, 2021). Magang sangat baik bagi mahasiswa karena selama proses magang mahasiswa akan didampingi oleh pembimbing lapangan yang akan melatih dan menasehati agar mahasiswa dapat belajar budaya kerja dan dapat berinteraksi dengan lingkungan barunya. Magang juga akan mengajarkan pada mahasiswa keterampilan baru sekaligus mengajarkan bagaimana bekerja (Liunir, 2012). Melalui kegiatan magang, mahasiswa juga akan menyadari bahwa apa yang telah dipelajari selama ini di kampus membantu menyiapkan masa depannya. Program magang tidak hanya memberikan manfaat bagi mahasiswa peserta magang, namun juga memberikan keuntungan bagi mitra yang memberikan kesempatan pada mahasiswa (Fatah, 2021). Program dari kebijakan akan berhasil apabila terdapat kesesuaian dari tiga unsur implementasi program kebijakan yaitu kesesuaian antara program kebijakan dengan penerima manfaat, kesesuaian antara program dengan organisasi pelaksana yaitu kesesuaian antara program dengan organiasasi pelaksana dan kesesuaian antara kelompok pemanfaat dengan organisasi pelaksana (Christianingrum \& Djumiarti, 2019). Kesesuaian kebijakan MBKM dengan Universitas Abdurrab sebagai bagian dari pelaksana program dapat diketahui dari persepsi sivitas akademik Universitas Abdurrab terhadap program MBKM tersebut di Universitas Abdurrab. Bahwa responden yang menyatakan sangat setuju sebesar $31,09 \%$, setuju sebesar 55,18\%, cukup setuju sebesar $12,89 \%$, kurang setuju sebesar $0,56 \%$ dan tidak setuju sebesar $0,28 \%$. Persentase tertinggi yaitu pada persepsi mahasiswa yang menyatakan setuju terhadap implementasi program magang dalam MBKM sebagai indikator kinerja utama di Universitas Abdurrab. Salah satu bentuk pembelajaran sesuai dengan Permendikbud Nomor 3 tahun 2020 pasal 15 ayat satu adalah program magang. Pimpinan tinggi Universitas Abdurrab yakni Rektor, WR I, II, III, serta Direktur Hubungan Masyarakat dan Kerjasama sepakat bahwa program magang akan memberikan pengalaman kepada mahasiswa. Selama proses magang akan mendapatkan pengalaman untuk menambah hardskills dan softskills, sehingga mahasiswa akan lebih percaya diri untuk memasuki dunia kerja dan karir di masa yang akan datang. Universitas Abdurrab telah melakukan magang di beberapa instansi terkait seperti Rumah Sakit, Puskesmas dan perusahaan. 
1345 Implementasi Kebijakan Merdeka Belajar Kampus Merdeka di Universitas Abdurrab pada Program Magang Mahasiswa - Amir Syamsuadi, Harni Sepriyani, Susi Endrini, Ade Febriani

DOI: https://doi.org/10.31004/edukatif.v4i1.2203

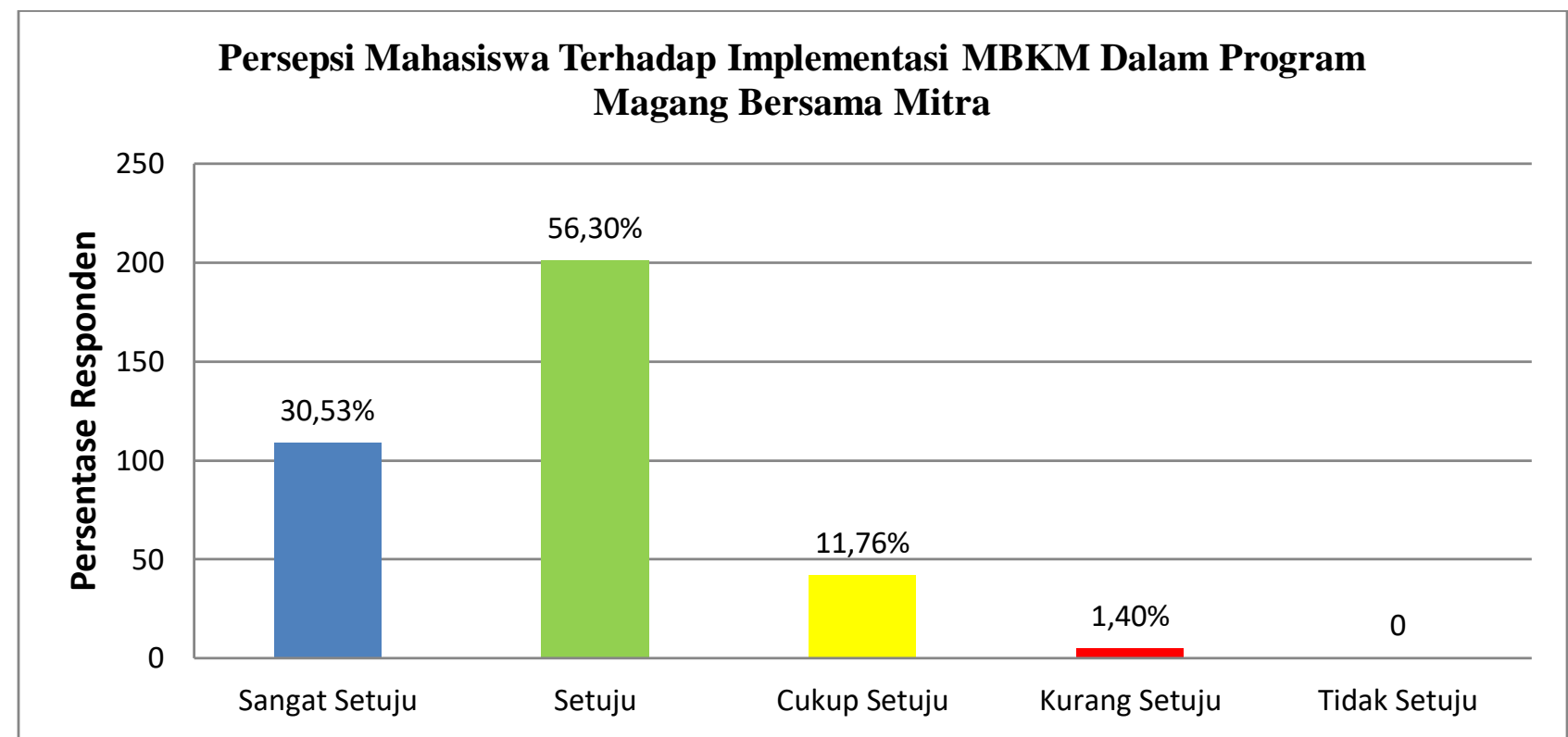

Gambar 1. Persepsi mahasiswa terhadap implementasi MBKM dalam program magang di Universitas Abdurrab

Pada persepsi mahasiswa terhadap implementasi MBKM dalam program magang. Responden yang menyatakan sangat setuju sebesar $30,53 \%$, setuju sebesar $56,30 \%$, cukup setuju sebesar $11,76 \%$, kurang setuju sebesar $1,40 \%$ dan tidak ada responden yang menyatakan tidak setuju. Persentase tertinggi yaitu pada persepsi mahasiswa yang menyatakan setuju terhadap implementasi MBKM dalam program magang. Program magang ini sangat disambut baik oleh mitra, karena melalui program ini akan terjalin kerja sama antara Universitas Abdurrab dengan mitra. Di samping itu, program ini juga dapat meningkatkan produktivitas instansi, karena mahasiswa dapat melakukan tugas-tugas kecil yang sebelumnya menjadi tanggung jawab karyawan instansi tersebut.

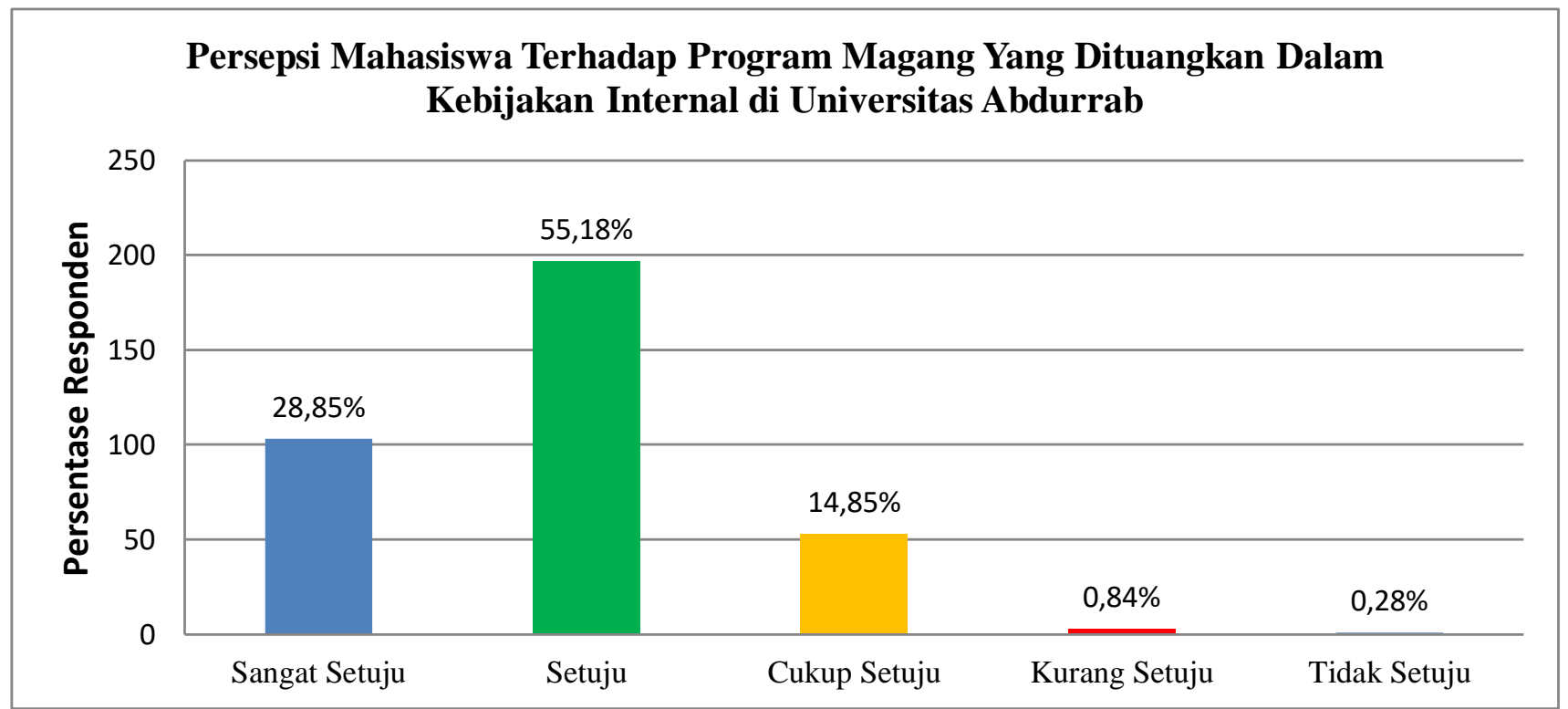

Gambar 2: Persepsi mahasiswa terhadap program magang yang dituangkan dalam kebijakan internal di Universitas Abdurrab.

Berdasarkan persepsi mahasiswa terhadap program magang yang dituangkan dalam kebijakan internal Universitas Abdurrab. Responden yang menyatakan sangat setuju sebesar 28,85\%, setuju sebesar 55,18\%, 
1346 Implementasi Kebijakan Merdeka Belajar Kampus Merdeka di Universitas Abdurrab pada Program Magang Mahasiswa - Amir Syamsuadi, Harni Sepriyani, Susi Endrini, Ade Febriani

DOI: https://doi.org/10.31004/edukatif.v4i1.2203

cukup setuju sebesar 14,85\%, kurang setuju sebesar $0,84 \%$ dan tidak setuju sebesar $0,28 \%$. Persentase tertinggi yaitu pada persepsi mahasiswa yang menyatakan setuju terhadap program magang yang dituangkan dalam kebijakan internal Universitas Abdurrab. Menurut Rektor Universitas Abdurrab, program magang ini telah dijalankan di Universitas Abdurab, tetapi belum adanya kesesuaian jumlah SKS magang mahasiswa Universitas Abdurrab dengan kebijakan magang MBKM SN Dikti, sehingga akan dilakukan penyesuaian melalui revisi kurikulum pada setiap program studi di Universitas Abdurrab.

\section{KESIMPULAN}

Berdasarkan uraian pembahasan di atas dapat disimpulkan hasil penelitian bahwa Universitas Abdurrab telah mengimplemetasikan kebijakan Merdeka Belajar Kampus Merdeka (MBKM) terutama dalam program magang mahasiswa yakni dengan menempatkan mahasiswa Universitas Abdurrab untuk melakukan magang di beberapa instansi terkait seperti Rumah Sakit, Puskesmas dan perusahaan. Universitas Abdurrab juga telah mengimplementasikan kebijakan MBKM untuk program magang mahasiswa seperti di Prodi D3 Analis kesehatan, Prodi S1 Kedokteran, Prodi D3 Keperawatan, Prodi S1 Teknik Sipil dan Prodi Teknik Informatika yang dijadikan Prodi percontohan pelaksanaan program magang di Universitas Abdurrab.

Adapun kendala dari pelaksanaan kebijakan ini diantaranya adalah belum adanya unit khusus untuk mempersiapkan magang mahasiswa dan belum adanya kesesuaian jumlah SKS magang mahasiswa Universitas Abdurrab dengan program magang MBKM SN DIKTI. Diharapkan kedepannya kebijakan MBKM Universitas Abdurrab perlu dipersiapkan dengan baik yaitu dengan membuat unit khusus terkait pelaksanaan magang mahahasiswa di Universitas Abdurrab. Peningkatan kerjasama Universitas Abdurrab dengan instansi lainnya sangat diperlukan dalam rangka untuk menyalurkan mahasiswa Universitas Abdurrab yang akan melakukan kegiatan magang, serta penyesuaian jumlah SKS untuk program ini dengan kebijakan MBKM berdasarkan Permendikbud Nomor 3 Tahun 2020. Hal ini semakin menguatkan temuan penelitian sebelumnya bahwa kebijakan MBKM yang ditetapkan oleh Kementerian Pendidikan dan kebudayaan Republik Indonesia terkait magang masih dihadapkan dengan persoalan teknis seperti kendala dalam menyepakati besaran sks magang dan rumitnya syarat administrasi kerjasama antar perguruan tinggi utamanya perguruan tinggi swasta. Penelitian ini terbatas hanya menggambarkan mengenai kebijakan MBKM magang mahasiswa di Universitas Abdurrab sehingga perlu ada kajian lanjutan untuk mengskplorasi lebih dalam mengenai kebijakam MBKM ini dalam ruang lingkup lainnya yang terdapat dalam 8 Indek kinerja Utama pada program Kebijakan MBKM, baik dalam skala lokal maupun skala nasional di Institusi perguruan tinggi yang ada di Indonesia.

\section{UCAPAN TERIMA KASIH}

Penulis mengucapkan terimakasih kepada seluruh pihak yang sudah turut serta membantu dalam proses penelitian ini. Terimakasih juga penulis sampaikan pada Ditjen Diktiristek atas Kegiatan Bantuan Pendanaan Program Penelitian Kebijakan Merdeka Belajar Kampus Merdeka Dan Pengabdian Kepada Masyarakat Berbasis Hasil Penelitian Perguruan Tinggi Swasta di Universitas Abdurrab.

\section{DAFTAR PUSTAKA}

Afitri, B. (2020). Evaluasi Kegunaan Sistem Informasi Akademik Universitas Abdurrab Menggunakan Metode Website Usability Evaluation. Universitas Islam Negeri Sultan Syarif Kasim Riau.

Agustino, L. (2008). Dasar-Dasar Kebijakan Publik, CV. Alfabeta Bandung.

Anggito, A., \& Setiawan, J. (2018). (2018). Metodologi Penelitian Kualitatif. CV Jejak (Jejak Publisher).

Christianingrum, S. I., \& Djumiarti, T. (2019). Implementasi Program Kota Tanpa Kumuh di Kecamatan Semarang Timur. Journal of Public Policy and Management Review, 8(2), 88-105. 
1347 Implementasi Kebijakan Merdeka Belajar Kampus Merdeka di Universitas Abdurrab pada Program Magang Mahasiswa - Amir Syamsuadi, Harni Sepriyani, Susi Endrini, Ade Febriani

DOI: https://doi.org/10.31004/edukatif.v4i1.2203

Dzikria, I., \& Narulita, L. F. (2021). Pengembangan Kurikulum untuk Pembentukan Jurusan Sistem Informasi Untag Surabaya Berbasiskan Kurikulum MBKM dan ACM IS dengan Metode Kualitatif. Proceeding KONIK (Konferensi Nasional Ilmu Komputer), 5, 229-234.

Fatah, A. (2021). Eksplorasi Dukungan Industri Mitra dalam Pelaksanaan Magang Pada Program Merdeka Belajar Kampus Merdeka. In Seminar Nasional Teknologi Pembelajaran (Vol. 1, hal. 282-290).

Ghulam, Z. (2020). Implementasi Kebijakan Magang dan Konseling Warga Berkebutuhan Khusus Di Surabaya. Dakwatuna: Jurnal Dakwah dan Komunikasi Islam, 6(1), 75-87.

Hayati, H. (2021). Evaluasi Peserta Magang Di Instansi Pemerintahan Dengan Metode Bekerja di Rumah (Studi Kualitatif sebagai Persiapan Magang Merdeka Belajar Kampus Merdeka). Jurnal Psikologi Pendidikan Dan Pengembangan SDM, 10(2), 54-71.

Kamalia, P. U., \& Andriansyah, E. H. (2021). Independent Learning-Independent Campus (MBKM) in Students' Perception. Jurnal Kependidikan: Jurnal Hasil Penelitian dan Kajian Kepustakaan di Bidang Pendidikan, Pengajaran dan Pembelajaran, 7(4), 857-867.

Kodrat, D. (2021). Mindset Mutu Manajemen Perguruan Tinggi Islam dalam Program Merdeka Belajar Kampus Merdeka (MBKM). Al-Mujaddid: Jurnal Ilmu-Ilmu Agama, 3(1), 48-61.

Krisnanik, E., Saphira, Q., \& Indriana, I. H. (2021). Desain Model MBKM Dan Kolaborasi Kerja Sama Model Pentahelix Guna Meningkatkan Daya Saing Lulusan. Proceeding KONIK (Konferensi Nasional Ilmu Komputer), 5, 138-142.

Laga, Y., Nona, R. V., Langga, L., \& Jamu, M. E. (2022). Persepsi Mahasiswa Terhadap Kebijakan Merdeka Belajar Kampus Merdeka (MBKM). Edukatif: Jurnal Ilmu Pendidikan, 4(1), 699-706.

Liunir, Z. (2012). Peran Magang Kewirausahaan di Bidang Busana bagi Pegembangan Budaya Wirausaha dan Kemampuan Kerja Mahasiswa Tata Busana di LPTK (Studi Kasus Magang di MQ Fashion Daarut Tauhiid Bandung). Prosiding APTEKINDO, 6(1).

Masrizal, M. (2012). Mixed Method Research. Jurnal Kesehatan Masyarakat Andalas, 6(2), 53-56.

Nasik, K. (2020). Model Pembelajaran Mata Kuliah Keislaman Berbasis Masalah Komunitas Yang Terintegrasi Sebagai Langkah Menyikapi Merdeka Belajar dan Kampus Merdeka (MBKM). Madinah: Jurnal Studi Islam, 7(2), 76-87.

Nona, R. V., Banda, F. L., Leha, E., Supardi, P. N., Meke, K. D. P., \& Suryani, L. (2022). Persepsi Dosen Universitas Flores Terhadap Program Merdeka Belajar Kampus Merdeka. Edukatif: Jurnal Ilmu Pendidikan, 4(1), 771-780.

Rohiyatussakinah, I. (2021). Implementation of MBKM and the Relationship of Curriculum Policy based on a Case of EFL Education in Japan. Journal of English Language Teaching and Literature (JELTL), 4(2), $39-50$.

Rosmiati, R., Putra, I., \& Nasori, A. (2021). Pengukuran Mutu Pembelajaran di FKIP UNJA dalam Upaya Membangun Generasi Economic Citizen yang Mengelaborasi Program MBKBM Kemendikbud. Edukatif: Jurnal Ilmu Pendidikan, 3(6), 5256-5264.

Sudaryanto, S., Widayati, W., \& Amalia, R. (2020). Konsep Merdeka Belajar-Kampus Merdeka dan Aplikasinya dalam Pendidikan Bahasa (dan Sastra) Indonesia. Kode: Jurnal Bahasa, 9(2).

Sugiyono, S. (2008). Metode penelitian kuantitatif dan kualitatif dan R\&D. Alfabeta Bandung.

Sulistiyani, E., Khamida, K., Soleha, U., Amalia, R., Hartatik, S., Putra, R. S., ... Andini, A. (2022). Implementasi Merdeka Belajar Kampus Merdeka (MBKM) pada Fakultas Kesehatan dan Non Kesehatan. Edukatif: Jurnal Ilmu Pendidikan, 4(1), 686-698.

Syamsuadi, A., Hartati, S., Trisnawati, L., \& Arisandi, D. (2020). Strategi Kebijakan Pengembangan Sagu Berbasis Sentra Industri Kecil Menengah (IKM). Jurnal Inovasi Ilmu Sosial dan Politik (JISoP), 2(2), 
1348 Implementasi Kebijakan Merdeka Belajar Kampus Merdeka di Universitas Abdurrab pada Program Magang Mahasiswa - Amir Syamsuadi, Harni Sepriyani, Susi Endrini, Ade Febriani

DOI: https://doi.org/10.31004/edukatif.v4i1.2203

$114-128$.

Yetnimar, Y., Nurjannah, N., \& Rasyid, A. (2020). Pengaruh Gaya Kepemimpinan, Gaya Komunikasi Pemimpin Terhadap Budaya Organisasi Dengan Perubahan Organisasi Karyawan Di Universitas Abdurrab. Jurnal Ilmu Komunikasi, 9(4), 567-589. 